\title{
Mythological Paradigms in the Greek Novels ${ }^{1}$
}

\author{
FRANÇOISE LÉTOUBLON \\ UNIVERSITY OF GRENOBLE
}

As a specialist in Homer, I have been interested in the textual links of the Greek novels, and particularly with Greek myths from the archaic period to the Hellenistic and Roman times. The important book published in 2004 by Edmund Cueva on The Myths of Fiction: Studies in the Canonical Greek Novels, far from exhausting the matter, renewed our interest in this field. The main idea in my paper derives from Malcolm Willcock's seminal articles on mythological paradigms in Homer (Willcock 1964; 1977). Reading the Greek novels, I felt they might show parallels with the argumentative use of myth as a paradigm in the Homeric cases of Meleager and Niobe, but this impression remained confused until a more precise research could begin. The clearer instances take place in Daphnis and Chloe, with interesting parallels in Leucippe and Cleitophon.

\section{Myth and Paradigm in Daphnis and Chloe}

Each of the three first books of Daphnis and Chloe contains an example of such a passage. ${ }^{2}$ As we will see, they are composed in a similar way, so that it could be called a 'formulaic style' in the Homeric manner: ${ }^{3}$ an oral narration concerning a young maiden is told to Chloe by Daphnis - in one case the tale is told by another character, whereas Daphnis and Chloe both mime the adventure they listen to. The young girl is in each case pursued by Pan, whom she does not want at all to love - those maidens are actually reluctant to respond to any kind of love and they prefer to disappear or to lose their human nature in a metamorphosis into an animal or a plant. ${ }^{4}$

The constant presence of the apostrophe in the vocative $(\pi \alpha \rho \theta \dot{\varepsilon} v o \varsigma, \pi \alpha \rho \theta \varepsilon \dot{\varepsilon} v$, in the first case, $\hat{\emptyset}$

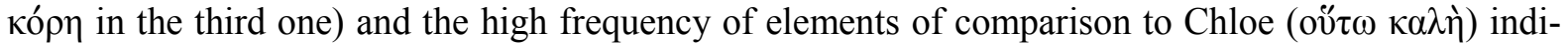
cate the status of paradigms: they are given as models for the young girl, who must learn a lesson through them.

The first example concerns a bird, pó $\tau \tau \alpha$ as a common name ('wood-pigeon'); under this same

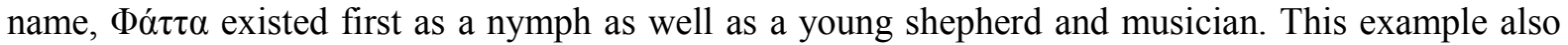
entails, in a very allusive manner, an inserted tale within a tale concerning a tree, who was herself once a young nymph called Pitys (the very name of the pinetree in Greek). Pitys rejected Pan's erotic impulses and was metamorphosed into the pinetree. We read explicitly that Phatta, crowned with pinetree branches, ${ }^{5}$ was singing Pan and Pitys. ${ }^{6}$

So the story of Daphnis and Chloe contains tales of several Nymphs who were the victims of the same dangerous god, and if we admit that the first instance of the device - Pitys behind and before Phatta - is a model for the other ones, those tales seem to include many similar stories, as if the fate of young girls eternally recurs with the terrible danger of being raped by this quasi-animal god. All of those girls can escape, but at the price of becoming part of the actual surroundings of Lesbos (the lo-

\footnotetext{
${ }^{1}$ I would like to thank C. Eades and J. Hallett for their help, Stephen Rojcewicz for his careful revision of my English, and the organizers of RICAN 5 for their invitation. I am grateful for the many comments made by the audience in Rethymnon. I am responsible for any remaining errors.

${ }^{2}$ On the series of 'included narratives', see Hunter 1983, 52-57; Morgan 2004, 171-172, 195-197; Bowie 2009.

${ }^{3}$ See the introduction by Pattoni 2005, 104, 112-116.

${ }^{4}$ As a common feature in most of the Ovidian metamorphoses.

${ }^{5}$ Chloe is herself crowned with pine-tree branches in 1,23,3: commemorating Pitys' story, it could be a symbol of virginity.

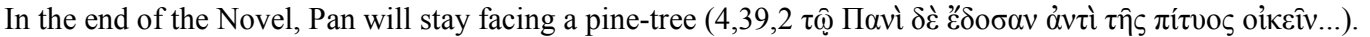

${ }^{6}$ On the importance of Pitys, see Morgan 2004, 172.
} 
cation for the story of Daphnis and Chloe). These maidens become: singing birds, trees that lightly move with the wind and offer their green leaves for crowning the hair of the maids, a musical instrument, and the phenomenon of the echo.

The case of Phatta and Pitys shows a tale within the tale, with a strong effect of mirroring the larger story we are reading; it recalls some of the devices of composition used in the Odyssey, and attested in some of the Platonic dialogues. ${ }^{7}$ The tale begins because the bird is heard singing and this song is so charming that Chloe wants to learn about it: the didactic role of the explanation is stressed in advance, before the narrator quotes Daphnis' words: 1,27 'a wood pigeon pleased them by singing a pastoral song from the wood. When Chloe wanted to know what its song meant, Daphnis taught her, telling her a story that had often been told. ${ }^{8}$

The first words uttered in Daphnis' discourse show the emphasis put on the comparison between Chloe and the former nymph: both are parthenoi, both are beautiful and they similarly care for cattle. Note that as in the frame narrative of Daphnis and Chloe, Phatta's cattle are supposed to appreciate her songs, so that the cows do not need to be pushed or prodded with a goad: 'She was a beautiful singer too, and her cows enjoyed her singing.'

Then comes the mention of the subject of her song, Pan and Pitys, with the phrase cited above, 'sitting under a pine and garlanded with pine, she sang the story of Pan and Pitys, and the cows stayed close to her voice.' Phatta's story is actually linked neither to Pan nor to love, but to a a competition with a boy who was both a shepherd and singer like her: they entered in rivalry, and his voice drew eight of her cows to his own cattle. ${ }^{9}$ Desperate by her defeat and loss, Phatta asked the gods to be metamorphosed into a bird ('the girl was distressed at the loss of her herd and at her defeat as a singer, and prayed to the gods to turn her into a bird before she arrived home'), and they fulfilled her prayer. We suggest that the content of the tale told by Phatta might be almost subliminally quite as important as the nice and sweet competition tale told by Daphnis.

The second occurrence of a myth told inside the narrative, in book 2, is more developed and amplified by the addition of a mimetic dance. It is first narrated by Lamon, Daphnis' adoptive father; then it is played on the syrinx while Daphnis and Chloe dance and mime the story being sung. ${ }^{10}$ It concerns a nymph called Syrinx and the same god Pan who tried to rape Pitys in Phatta's tale; it is an aetiological tale for the invention of the music instrument which is essential for the young lovers throughout the tale. 2,34-37.

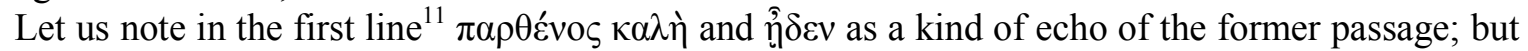

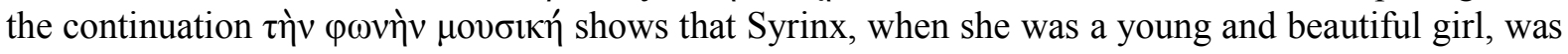
already related to the Muses, more than simply gifted for singing; this gift for music draw Pan to her, and he proposed a bargain concerning her love. She just laughed at this proposal ('But she laughed at his love and said that she'd never accept as a lover a creature who wasn't completely goat or completely man') with a pun on his half-animal nature that must have been very hurtful for him. He tried to rape her, so she ran away ('Pan started to chase her, intending to use violence') and hid herself in the bulrushes, disappearing into a marsh. Pan, disappointed in his erotic hopes - as it seems to happen constantly: we actually do not know many successes in his enterprises in Greek literature... - cut the bulrushes in his anger, but did not find her, and he invented the instrument to play music with them. The end of 2,34 is then devoted to the technical character of the syrinx, with its unequal pipes, that symbolize their unequal relation. ${ }^{12}$

\footnotetext{
${ }^{7}$ See Létoublon 1983.

${ }^{8}$ All translations are from Reardon's Collected Ancient Greek Novels (1989).

${ }^{9}$ Therefore it reminds of several mythological tales told in Ovid's Metamorphoses, like Athena and Arachne, Apollo and Marsyas. Antoninus Liberalis tells an interesting version of Aedon and her sister Chelidon, where Aedon enters a competition in technical work with her husband Polytechnos. See also Athena and Pallas in Apollodorus.

${ }^{10}$ In the wake of my former study (n.6), this reduplication could be one of the devices of a reflective text, like tale in the tale in the case of Phatta singing Pitys.

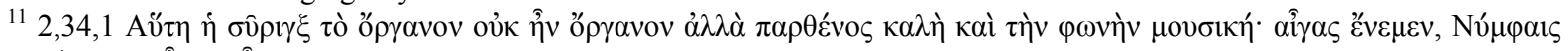

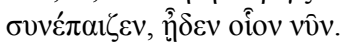

${ }^{12}$ Ch. Gill's translation, in Reardon (ed.) 1989, does not take into account this important detail, as if he had a different text. In the parallel story told in Achilles Tatius, the inequality of the pipes receives still more emphasis, but no comparison to Pan's relation with the nymph is expressed. It may thus be asked whether it comes from Longus' own poetic invention.
} 
The beginning of 2,35 is also striking because of the use of the literary lexical means. 'Lamon had

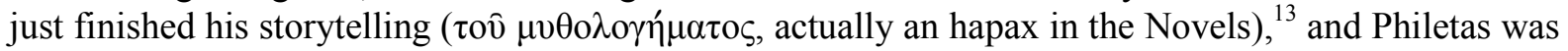

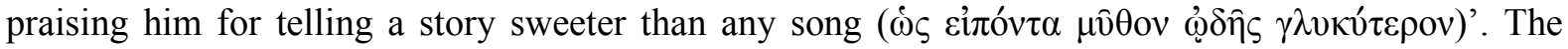
word $\mu v \theta \mathrm{o} \lambda$ ó $\gamma \eta \mu \alpha$ well shows that the author was aware of the significance of this mythological narrative: as said above, the reflective dimension is essential. Philetas' congratulations towards Lamon's narrative quality go on in this vein, and show a kind of competition between telling a story and singing that reminds us of the prologue and its competition between the painting seen in a cave of the Nymphs and the desire to tell a similar story. ${ }^{14}$

The story told by Lamon finds a kind of echo in the text, through Philetas' playing the syrinx brought by Tityros. It is important that this syrinx seems to be the very instrument invented by Pan in the former paragraph: 'You could have imagined it was the very instrument that Pan first put together.' We meet here with one of the author's remarks on the similarity between the 'real' world pointed to in the frame of the novel, the world Daphnis and Chloe are living in, and the other world of the tales told as mythoi. Is it possible that Philetas inherited Pan's very syrinx? Anyhow, Philetas' music seems to please the audience as far as it imitates the sounds of life: 'he played music that fitted a herd of cows, music that suited a herd of goats, music that flocks of sheep would love.'

Furthermore, for a third time, Daphnis and Chloe begin to dance, miming the story heard, imitating Pan and Syrinx: 2,37 'Daphnis took the part of Pan, and Chloe the part of Syrinx. He begged and tried to talk her round; she smiled indifferently. He gave chase, running on tiptoe to give the impression of having hooves; she acted as if she were tired of running away.'

This passage emphasizes the mimetic pleasure, and suggests that dancing the pathos of Pan and Syrinx, along with music-playing, is the acme of the whole episode. The length of this three-fold passage heightens its importance in the whole story.

As we met instances of mythological paradigm in book one and two, we may anticipate another such narrative in book 3, the story about the nymph Echo and Pan, in 3,23. ${ }^{15}$ Though the whole passage is shorter than Syrinx's myth, the introduction of the myth is more developed than in the former instances, with an allusion to other Nymphs; we still meet the apostrophic vocative (kore): ${ }^{16}$ 'My dear girl, there is a great family of Nymphs: there are Nymphs of the Ash, Nymphs of the Oak, and Nymphs of the Meadow. All of them are beautiful, and all of them are sweet singers. One of them had a daughter called Echo, who was mortal because she had a mortal father, but was beautiful because she had a beautiful mother.'

This third item recalls the first one, though the comparison with Chloe's beauty is not explicit there - we may think it goes without saying since it has been said initially about Phatta. Anyway Echo is also $\kappa \alpha \lambda \eta$, and as the daughter of a Nymph playing with the Muses, she has the same relation to music as Syrinx ('She was brought up by the Nymphs, and taught by the Muses to play the pipes, the flute, the lyre and the cithara, and to sing songs of every kind. When she grew up and flowered into a lovely girl, she danced with the Nymphs and sung with the Muses'); the music instruments mentioned are lyra and kithara, usually linked in Greek culture to high genres, particularly epos. But the verbs

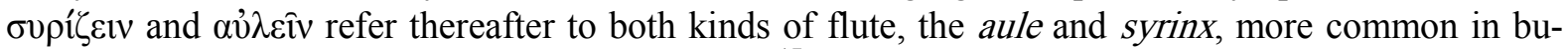

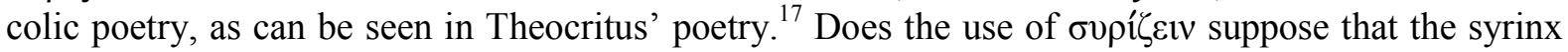
already exists as a music instrument, and therefore that the myth told in book 2 occurred before this one in book 3 , in a kind of relative chronology of mythology?

Thereafter in this musical context comes crucial information: this nymph devoted herself to vir-

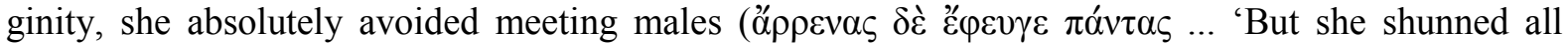
males both human and divine, loving her virginity'). In the former instances, the character of Pan was not developed, it is more stressed here that he cannot stand this kind of despising: since he becomes

\footnotetext{
${ }^{13}$ The $T L G$ gives about 50 instances of the word, the half of them in Byzantine Greek authors.

${ }^{14}$ On the three tales, see Bowie 2009, particularly for this passage p.123. On the second myth of the series see Morgan 2004, 195-197. See later the remark on the birth of the so-called paragone because of a phrase recalling Simonides' aphorism.

${ }^{15}$ And it could be asked why there is none in book 4.

${ }^{16}$ On the repetitions in Daphnis and Chloe as a device that could come from Homer, see Pattoni 2005, 104, 112-116, quoted above.

${ }^{17}$ Létoublon 2005.
} 
mad with this indifference, he strikes at her by making her cattle mad, which reminds us of Phatta's losing eight of her cows, and, of course, the problems met by both Daphnis and Chloe with their own cattle: 'Pan was angry with the girl, because of his jealousy of her musical artistry and because of his failure to enjoy her beauty'. The goddess Gê (Earth), who likes hearing her voice, lets her disappear entirely with her cattle, preserving her gift for imitating sounds heard, be it a voice, an instrument or an animal, with a pun on the word $\mu \varepsilon \dot{\lambda} \lambda \eta$ meaning both 'songs' and 'limbs': 'As a favor to the Nymphs, Earth hid all her limbs and preserved their music; and by the will of the Muses, Earth has the power of speech and copies everything, just as the girl did then - gods, men, instruments, beasts.'

So echo, now a common name for a natural phenomenon, even imitates Pan playing panpipe, so that his own erotic desire grows, and he still pursues her: 'and when he hears it, he jumps up and chases over the mountains. All he wants now is to know who his invisible pupil is.'

If we compare the version of the Echo-story told by Longus to that told by Ovid in the Metamorphoses we note several important differences: ${ }^{18}$ the character of Echo is not in love here, but she runs away from Pan's dangerous love, actually from every male person: it seems that Pan is only the worst of them. No Narcissus here. Instead of being transformed into stone cliffs that produce the phenomenon of echo, Longus' Echo merely disappears in the air or rather in the earth, which reminds us of Syrinx's disappearing in the marsh. Pan's disappointment may be interpreted as a symbol of the vanity of any physical desire, which cannot ever find full satisfaction. The common feature in these three myths where Pan plays a role, seems to be that the god, in his disappointed or deceived longing for a young girl, gives birth to a metamorphosis: Pitys into the pine-tree, Syrinx into the music instrument, and Echo into the natural phenomenon. This feature also appears, in a quasi systematic manner, in Ovid's Metamorphoses, which could be explained by a general attitude of Greek myths towards the natural environment, and by Ovid's borrowing from lost Greek models, as Cameron (2004) demonstrated.

\section{Eros, a myth in a reflective tale}

Apart from those characteristic paradigmatic myths, a long narrative with an officially didactic aim is told in book 2 by the old Philetas to both Daphnis and Chloe. ${ }^{19}$ The character himself is very interesting: his name might mean something like 'Love', but above all, he recalls a famous Greek bucolic poet, who was probably the protos heuretes of the genre, prior to Theocritus. ${ }^{20}$ Since the god Eros plays an important role in the frame narrative, the inserted tale takes on a crucial reflective value.

As in the short Hellenistic epigrams, Eros' effects are first described without a revelation of his identity, until Philetas explains that he saw his attributes (bow and arrows, wings) and eventually calls him by his name, with a very characteristic (and poetic) anaphora (2,6 f.). I still want to stress the paradigmatic value of the tale: Philetas was in love with Amaryllis (like Daphnis and Chloe now), he endured the same symptoms of illness, cold and heat, as Daphnis and Chloe are now enduring, after Sappho's well-known model: 'I was young myself once and fell in love with Amaryllis. I forgot to eat; I didn't drink; I couldn't sleep. My soul was in pain; my heart pounded; my body was frozen

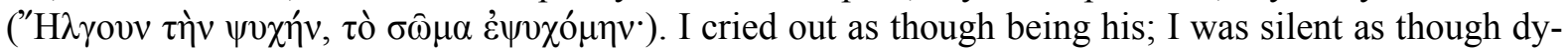

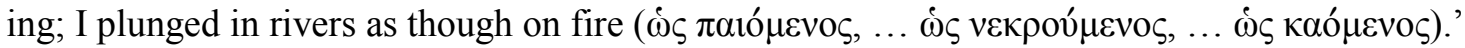

And in a very interesting manner, Philetas even tells that he then called on Pan for help, because he is a male, in a different situation from the Nymphs of the three other myths; but notice that in the novel, Pan plays a protective role as well for Chloe: it may be supposed that the musical activities he practised and even invented through his mythical misadventures in the past has in some way appeased his libido): the sentence anyway contains a clear allusion to Pan's love for Pitys, confirming our analysis of the myth of Pitys within the mythological tale about Phatta in book 1: 'I called on Pan to

\footnotetext{
${ }^{18}$ See Gély-Ghédira 2000.

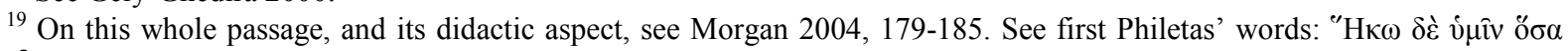

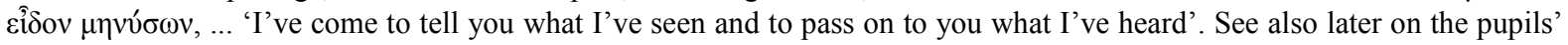

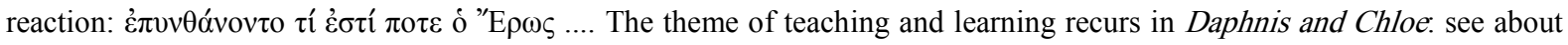
Lycaenion 3,17,2; 3,19,1.

${ }^{20}$ On Philetas' character as a feature of intertextuality, see Morgan 2008, 219. See another view in Di Marco 2000.
} 
help me, since he himself had been in love with Pitys. I praised Echo for calling after me the name of Amaryllis.' In other words, he came to 'sublimate' his erotic impulses.

The most important mythical figure in Philetas' discourse is of course Eros, particularly through his description in the garden in the typical ideal manner analyzed by Curtius. The young boy is described only from outside, with comparisons ('His skin was white like milk, and his hair was reddishgold like fire, ... sometimes hiding under the poppies like a young partridge'), with anaphorical adjec-

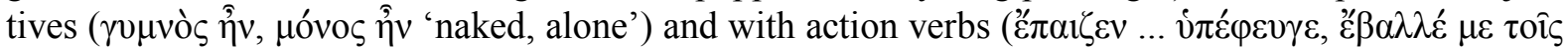

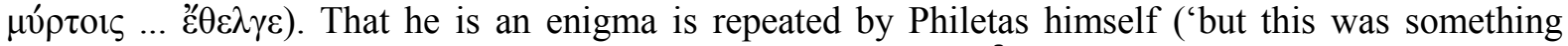

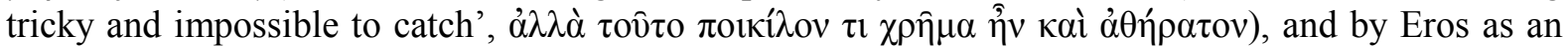
answer to the question asked by Philetas: 'And I'm hard to catch, even for a hawk and an eagle and any bird faster than these. I'm not really a boy, even though I look like one, but I'm even older than Cronus and the whole of time itself. I've known you when, as a lusty young man, you used to graze your large herd of cows on that mountain there, and I've been with you while you played the pipes beside those oaks when you were in love with Amaryllis. But you didn't see me, although I was standing very close to the girl.') The boy does not tell Philetas his name, but reveals that he is now the

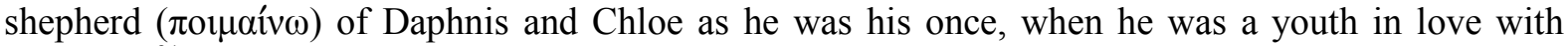
Amaryllis ${ }^{21}$ ('Well, I gave her to you, and now you have sons who are good cowherds and farmers. At the moment, Daphnis and Chloe are the flock I am looking after.'). Thereafter only Philetas tells how the young boy fled away with his bow and arrows: 2,6 'He said this and then hopped like a young nightingale into the myrtles ... I saw wings growing from his shoulders and a little bow between his wings, and then I saw neither them nor him.'

At the very end of his narrative, Philetas unveils the name of this enigmatic (at least for the young pupils he is teaching) paidion, and there with a repetition and a poetical rhythm very typical of

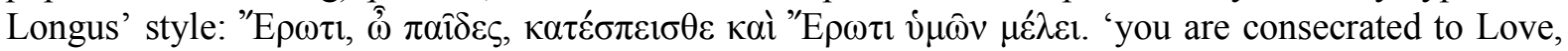
my children, and Love is looking after you.' Philetas still goes on, stressing more and more Eros' powers, that he deems stronger than Zeus' himself: 'Love is a god, my children; he is young, beautiful, and winged; ... Zeus has not so much power as he has: he rules the elements; he rules the stars; he rules his fellow gods...'

This specific claim made by Philetas, though rather common in Greek literature, seems to me interesting for explaining the importance of Eros in the novel, in itself a kind of landmark for the whole genre. ${ }^{22}$ Though the novel is not recognized as such in critical works until the European Renaissance, the authors themselves seem to point to their work with the plural neuter $\dot{\varepsilon} \rho \omega \tau \imath \kappa \alpha ́$ or the periphrases such as "Е $\omega \tau$ ' $\pi \alpha \dot{\alpha} \theta \eta$ 'Love stories' ${ }^{23}$ Philetas' narrative thus appears a very exemplar for the whole genre, at least for the sub-genre characterized as 'idealistic'. Furthermore, this claim meets with a parallel in the beginning of Leucippe and Clitophon: in the famous ekphrasis of a painting showing the Rape of Europa seen in the shrine of Astarte in Sidon, 1,2: 'Though the entire painting was worthy of admiration, I devoted my special attention to this figure of Eros leading the bull, for I have long been fascinated by passion, and I exclaimed, 'to think that a child can have such power over heaven and earth and sea."

This coincidence leads us to examine Leucippe and Clitophon for myths used as paradigms.

\section{Parallels and differences in Leucippe and Clitophon}

Book 1 of Leucippe and Clitophon contains an interesting parallel to the mythological paradigms in Daphnis and Chloe: the same kind of oral narrative, the same claim to teaching, and particularly the young girl, here Leucippe; instead of putting on the stage one and the same narrator, be it Daphnis for

\footnotetext{
${ }^{21}$ The girl loved by Philetas was called Amaryllis, which reminds us of the best known of Virgil's Eclogues. Daphnis and Chloe also features a Tityros, who faces us with the same issue. Some critics thought that Longus read Virgil, but the coincidence might be explained by a same Greek source for both of them. Theocritus' remaining poetry provides several parallels for both authors. See Morgan 2004, 183.

${ }^{22}$ On the genre of the novel, see Selden 1994, Goldhill 2008 with earlier references.

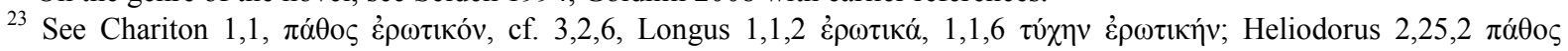

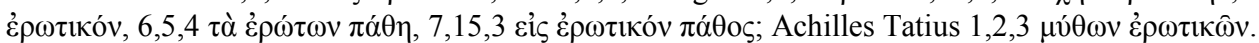


Chloe or Philetas for both of the characters, the brilliant Achilles Tatius distributes the role of narrating several myths following each other to two boys in dialogue, with a play on the roles of the addressee: in 1,16-18 both Satyros and Clitophon speak as if they would address each other, while both of them actually speak for Leucippe ${ }^{24}$ who is wandering in the paradeisos with Clio: he takes first the

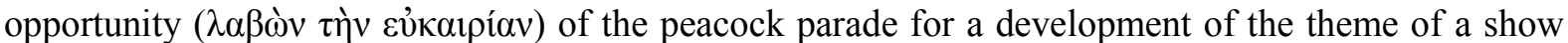
staged by the male for enticing the female. Thus the character appears as organizing the play, as a theater director, ${ }^{25}$ who drives the girl's eyes towards a stage so that he can better succeed in his own aim. He portrays the peacock as an actor in a theater ('the peacock, who at this very moment ... spread his beautiful tail and showed the amphitheater of his feathers'), and turns the attention towards the bird's tactic ('He does this by design', I said, 'for he is a lover. He uses his gorgeous resources thus when he wishes to arouse his mistress.'). Clitophon's own strategy is modeled on this love parade, but the girl is too young and naïve for such a distant reflection.

Satyros, Clitophon's servant and accomplice, begins to speak with the same argumentative target ('understanding the reason for my speech'), and the dialogue develops four examples that refer to the biological and mythological tradition: the Magnetic stone, the palm tree called phoenix, the 'sea-

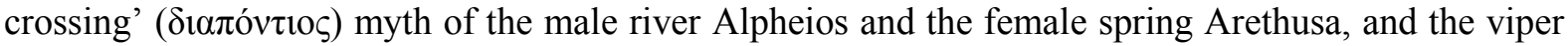
and murena. We shall come back later to the second example; let us now stress the argumentative intention of Satyros' narrative, in continuity of Clitophon's one. Clitophon's words were intended to turn Leucippe towards love, or at least to prepare $(\pi \alpha \rho \alpha \sigma \kappa \varepsilon v \alpha$ ó $\alpha$ ) her to look at him and admire him like the female bird who looks at the peacock's parade. In a similar spirit, the examples show how strong love is: Satyros' question puts Eros in the first plane of the discussion, so that the stone, the palm tree, the river and spring, and the reptiles all appear as instances of love in the domains of nature:

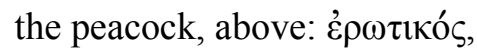

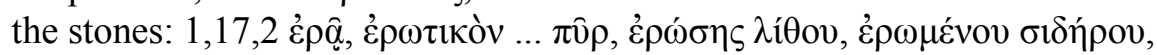

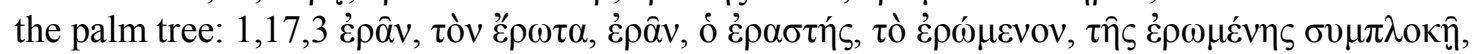

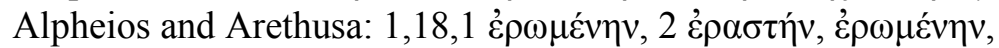

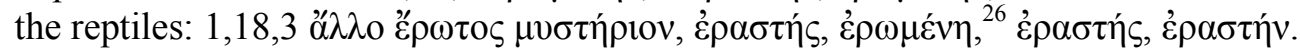

The love strategy is very deliberate, since after the end of this discourse, Clitophon, looking at Leucippe's face, sees her as a beautiful flower meadow, and complacently describes it, but comes with Satyros to the progress of his affair and the success of the dialogue they held $(1,19,3)$, accurately using the word mythologia. ${ }^{27}$ The strategy continues at the beginning of book 2 , when Clitophon and Satyros both enter the girl's room; Clitophon cannot help looking at her, even for a while $(2,1,1)$. The myth of the origin of the wine $(2,2)$ has a more decorative function, which might help us to understand the use of myths as a paradigm is: the characters tell them with a demonstrative intention, they want the myth to provoke an echo in life.

Myths also appear in paintings, at first sight with a decorative function, in the wake of the ekphrastic mania in the time of 'Second Sophistic': ${ }^{2}$

- Europa and Zeus as a bull, as the opening of the novel $(1,1,2-13$, ending with the detail of the description of Eros as a winged child driving the bull, just before the character exclaims as quoted above: 'And Eros was leading the bull: Eros, a tiny child, with wings spread, quiver dangling, torch in hand. He had turned to look at Zeus with a sly smile, as if in mockery that he had, for Love's sake, become a bull').

- Andromeda and Perseus in parallel and visual symmetry with Prometheus and Heracles.

\footnotetext{
${ }^{24}$ 1,16 Clitophon and Satyros here play roles, see Létoublon 1993, 154-155 on other 'ritual idioms' of the lovers.

${ }^{25}$ On the use of theater terminology in the novel, the study published by Walden in 1894 on Heliodorus may be extended: see Crismani 1997.

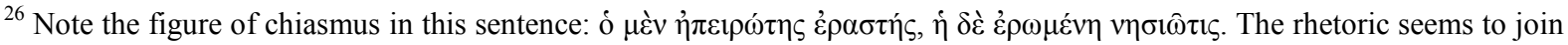
together both of the lovers, whereas their origins (continent/island) oppose them.

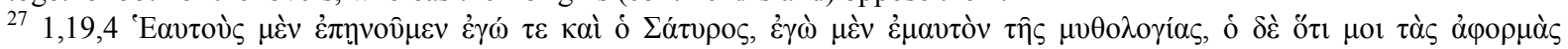
$\pi \alpha \rho \varepsilon ́ \sigma \chi \varepsilon v$.

${ }^{28}$ See Bartsch 1989 on ekphraseis in Achilles Tatius and Heliodorus.
} 
- Tereus, the lark and the nightingale, 5,3,4-8 and 5,5,2-9. ${ }^{29}$ This instance may appear as a paradigm because it begins as a confirmation of the wonder just seen by the characters and the question of intelligibility: 'O Zeus, what are you trying to tell us by this sign? If you have really given us this bird as a warning, please send your message again in a still more perspicuous sign. Then, turning around, I happened to face an artist's studio and saw a painting on display whose allusions could but confirm the ominous bird. It showed the rape of Philomela, Tereus attacking her, her tongue cut out. The plot of the drama was there in every detail - the robe, Tereus, the banquet. A maid was holding the unfolded robe; Philomela stood beside her and pointed to the pictures she had woven').

As if the narrator was not sure that the reader understood the meaning of the myth, the question of the interpretation is asked twice, the first time by by Clitophon who directly addresses the supreme god, and receives as an answer the sight of the painting exhibited in a painter workshop; the second time by Leucippe ${ }^{30}$ for the sake of a general taste by women for listening to fables $(5,5,1 \varphi \imath \lambda o ́ p v \theta o v)$. So the text says twice that a meaning is required; this requirement could be extended to other cases, and maybe to the whole of Greek myths, and to the origin of mythology in the fundamental issues addressed by mankind. If the narrative asks questions through telling and showing a myth, such as the story of the Thracian Tereus and the Pandareids, no explanation is given: the myth seems to stand as a question for itself. So, if we follow Achilles Tatius on this trail, we could conclude that the myths do not explain anything, but instead pose questions, they help men in their thinking. We might take in earnest the use by Menelas of the word $\sigma 0 \mu \beta o \lambda o v:^{31}$ an event or an object which refers to another event or object, the real world pointing to another world. Myths are crucial in the search for meaning, they do not necessarily spell out that meaning.

The second commentary on the painting by Clitophon is in my opinion the most interesting, as it stresses the role of Philomela's tongue, giving in Greek an equivalent to the Ovidian version of this

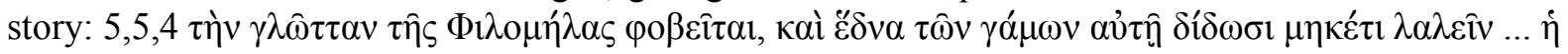

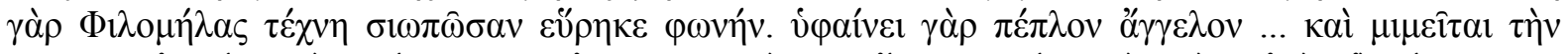

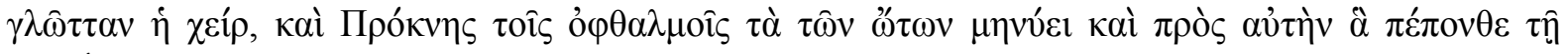
$\kappa \varepsilon \rho \kappa i ́ \delta ı ~ \lambda \alpha \lambda \varepsilon i ̂$. 'He feared Philomela's tongue, and his wedding present to her was the gift of silence. He snipped off the blossom of her voice. But even this was ineffectual, for Philomela's skill discovered voiceless speech. She wove, you see, a robe as messenger, and she threaded the drama into her embroidery, hand imitating tongue; she conveyed the ear's message to Prokne's eyes, telling her what she suffered by means of her shuttle.'

The text probably keeps in memory the famous aphorism on painting and poetry by Simonides, ${ }^{32}$ and plays on the paradox of speaking vs. silence; $\tau \hat{n} \kappa \varepsilon \rho \kappa i ́ \delta ı ~ \lambda \alpha \lambda \varepsilon \hat{\imath}$ 'she talks with her shuttle' also recalls the fragment of Sophocles' Tereus known through the quotation in Aristotle's Poetics. ${ }^{33}$ it appears as a passage very deeply charged with bookishness and literary knowledge. Of course, Achilles Tatius did not intend to show how learned his hero was. He rather wants the learned reader to recognize those signs and have a kind of smile of connivance. ${ }^{34}$ Moreover, the repetition of questions on the sense of the myth and its image and the stylistic emphasis all point to the importance of this bloody story. It is not a paradigm, but this myth announces deeds to come: during the following night, Leucippe is raped by brigands and at this sight, Clitophon throws himself on the brigands' swords, receives an injury, and despite all his body injuries, wants to be on the boat on which the strategos has been pursuing them. ${ }^{35}$

\footnotetext{
${ }^{29}$ On this peculiar ekphrasis, see the fine analysis by Dubel 2006.

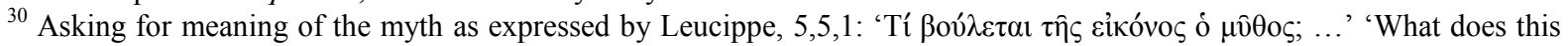
picture mean? In the story, who are these birds, and the women, and that awful man?'

${ }^{31}$ 5,4,1 (Menelaus is speaking): 'You see these two unfavorable sings: the bird's aggressive wing and the threat implicit in this painting. Interpreters of signs tell us to consider the story of any painting we chance to see as we set out on business.'

${ }^{32}$ Plut. De gloria Athen., Mor. 88.347, the main ancient source whence the so-called paragone derived. See also id. Quomodo adolescens poetas audire debeat, Mor. 68.18 .

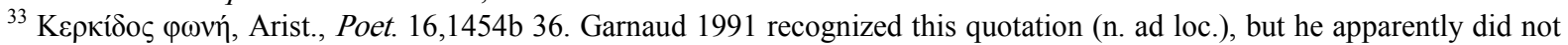
see the allusion to Simonides' aphorism.

${ }^{34}$ See also the images of the Erinyes cooking $(5,5,8)$ and the rhetorical allure of the sentence, 5,5,7.

${ }^{35}$ Thus he will see from his bed on the boat the girl' head cut, the second apparent death episode of his beloved.
} 
Moreover, two other events in the novel show myths playing a first-place role, since they act as a proof of virginity or faith, through an ordeal, as the account of their aetiology explains: first the myth of Syrinx, parallel to the story mimetically danced in Daphnis and Chloe, receives the charge of proving Leucippe's virginity, 8,6,3-10. The mythological narrative takes place in Artemis' shrine, in a sacred wood behind the temple, near the cave where the test will happen. The narrative is placed in the mouth of a priest, thus somehow sanctified. He first explains the shape of the syrinx hanging in the cave, with its unequal bulrushes that produces harmony: 8,6,5 'The reason ( $\alpha$ iltiov) for such a ranking

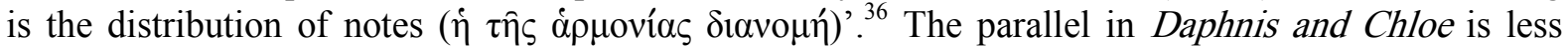
technical, but explains this shape as a symbol of the unequal relation between Pan and the Nymph Syrinx. But the rush and pursuit of the girl by the amorous god and his eventual disappointment fea-

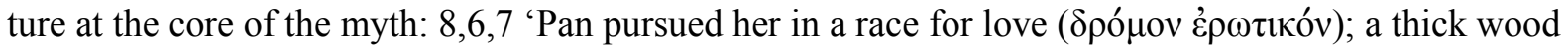
received her in her flight. At that moment, Pan, who was right on her heels, reached out his hand to

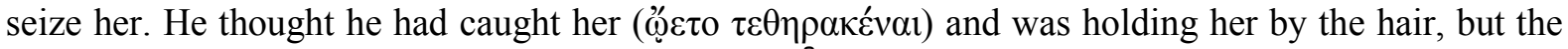

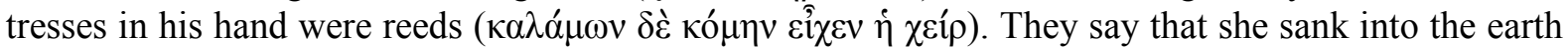
and that the earth produced reeds in her place. Pan cut the reeds angtily for concealing the object of his desire'.

As in both cases of Syrinx and Echo in Longus' narratives, the disappearing of the nymph expressed here by the perfect infinitive $\lambda \varepsilon \lambda \nu \sigma \theta \alpha \mathrm{l}$ (8,6,9 'he thought the maid had been changed into the reeds and wept that he had cut her, supposing his beloved had been slashed'), causes the metamorphosis of the bulrushes into the music instrument, as a substitute for a recall of the girl to life: the image of dismembering and reconstructing the body is very striking here $(8,6,10$ 'Gathering up the severed bits of reed as if they were the limbs of her body and joining them together as a single body, he held in his hands the cut ends of the reeds and kissed them as if they were the maiden's wounds. $\mathrm{He}$ groaned as he put his lover's lips to them and so breathed into the flutes from above as he kissed them'); the music produced by flowing in the bulrushes becomes the metaphor of her respiration ('His breath flowed through the narrow reed passages and made flutelike sounds: the syrinx had a voice'). The whole process indicates a replacement of the girl by the instrument, which Pan eventually kisses as if it were the girl's face and mouth.

This very instrument, exhibited in the cave as an anathema to Artemis, is supposed to sing by itself, as if Pan himself was playing, if the girl entering is a virgin, whereas if a woman had lied about her virginity, this would provoke, not melodious music, but a horrible scream. Thus the syrinx is a proof of virginity. Leucippe is sure of being pure: though she encountered pirates, brigands and powerful men who were in eager to have sex with her, she escaped all those dangers, and Clitophon did not have any actual occasion for making love with her. The test of virginity mixes religion and right: the priest and the court cannot be distinguished.

The second aetiology of a test as a proof of virtue is another cave, called 'Styx's water' $(8,12,1)$, given as part of Clitophon's narrative. It is intended to explain why Melite's faithful claim is true or not, and the narrator plays with the reader's sense of anticipation, delaying the report of the test to the following day $(8,11,4)$. This gives the opportunity for the aetiology: a young girl called Rhodopis took part in Artemis' hunting $(8,12,1)$ and swore that she would never 'undergo Aphrodite's violence' $(8,12,3)$. In the same place of Ephesos, the young Euthynicos was also eager for hunting and swore he

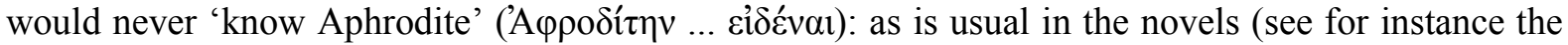
thread of Xenophon's Ephesiaca and the character of Habrocomes), the goddess could not stand such abhorrence of love, and she sent her son Eros against Rhodopis. Rhodopis killed a doe, but in the same time received Eros' arrow in her heart. Rhodopis and Euthynicos then saw each another, immediately fell in love and betrayed their oath in this very cave. Seeing Aphrodite laughing at this treachery, Artemis changed the girl into water in the very place where she lost her virginity, and this cave is 'now' a test for truth-telling or lying concerning virginity.

Achilles Tatius is still playing with parallelisms: Rhodopis and Euthynicos both swore they would never fall in love, like Hippolytos in the most known Greek version of the devotion to Artemis, or like Callisto in Ovid's Metamorphoses. Rhodopis here recalls Anthia in the Ephesiaca. But the agon be-

\footnotetext{
${ }^{36}$ Numerous technical details are given in the text, that I leave aside here.
} 
tween Artemis and Aphrodite is made unequal since Artemis is alone, while Aphrodite has with her her son Eros, armed with a bow like Rhodopis. On behalf of his mother, Eros drives an arrow against the girl whilst she aims her arrow towards an animal (a doe): both of the arrows touch the target, Rhodopis and Euthynicos make love in the cave, and Artemis changes the girl into the water of the spring; the text does not explain Euthynicos' fate.

The symmetry of those narratives produces the successive moves of the court to both places where Leucippe first, and then Melite, are both proved innocent: 8,14, Leucippe in the cave produces the sweetest syrinx music ever heard, and Melite stays in the Styx water without any overflow. Of course, the reader know that Melite's truth is not the whole truth, and that Clitophon also did not tell the whole truth about their relationship: he had slept with her, but they had sex only after Thersandros' return, whereas Melite's oath written on the tablet hanging on her neck claimed that she did not made love with him before her husband's return.

These episodes serve as paradigms since both of the females involved show their characters to be modeled on the mythical one, but without its tragic ending. Like Syrinx, Leucippe escaped the dangerous desire of her would-be-rapists, but she did not disappear like her model. The use of sophistic makes the similarity between Rhodopis and Melite less convincing: Rhodopis, under Aphrodite's and Eros' influence, was unfaithful to her betrothed, and metamorphosed into water, she now has the charge of proving faithfulness or falsehood. Melite's swearing is faithful only as far as the temporal restriction is taken into account. The test by water is formalistic, and accepts the reservation.

The parallels between Daphnis and Chloe on the one hand, and Leucippe and Clitophon on the other, are quite striking, particularly for the use of Syrinx's myth. But though the use of myth is far more sophisticated in the second novel, the freshness of the first one and its deep intricacy in the symbolic intention of showing the sexual violence by Pan's character on a young maiden is meaningful.

Let us come back to the presence in the text, between other narratives by Satyros and Clitophon, of the development on the Magnetic stone: in an article to appear, we show that this metaphor for love attested in tragedy, is developed in the Platonic theory of both love and of poetic inspiration. Here it gives a Platonic tone to the whole exchange. ${ }^{37}$

Among the uses of myth in the Novels, as in Homeric poetry, we saw several instances of myth as a paradigm for the young inexperienced heroes: these stories of old times may help instruct the youths how to behave in the awful events they have to face. From the explicit use as paradigm in Daphnis and Chloe and the parallel, but more sophisticated, mythical stories in Leucippe and Clitophon, it may be inferred that the use as paradigm, although not always the case, is frequent. Though both novels appear very different from each other in many features, the similarities are striking. The similarities could come from the awareness in both that things and beings in nature are the imitation of an other, and result from a metamorphosis: ${ }^{38}$ thus a cave, a tree or a bird, is not simply a cave, tree or bird, but a nymph is there in a mysterious way, and the whole world resonates with echoes of former living beings. The case of Echo could be taken as a symbol of this presence which make nature 'full of gods'. It is particularly striking in the description of gardens and caves, where art imitates nature, but nature itself seems an imitation. Once more, Achilles Tatius is especially sophisticated on this point. ${ }^{39}$

I left Chariton aside, because in Chaireas and Callirhoe the examples of mythological paradigms did not appear as clearly as those in both Longus and Achilles Tatius. But it may be asked why this use was not met in Heliodorus' Aethiopica for all the subtlety of this peculiar novel. The answer could be that this very subtlety surpasses the telling of myths as well as it does not need to use as many explicit metaphors as the other ideal novel. The metaphors of athleticism and of the magnetism of Love do underlie the text, but they do not need an explicit expression like those met in Chariton, Achilles Tatius or Longus. In the Aethiopica, the myth of Andromeda rescued by Perseus actually underlay the text, as the allusion to the painting in the royal bedroom of Persinna and Hydaspes in the linen band

\footnotetext{
${ }^{37}$ The Platonic tone in Achilles may be due to a philosophical literacy that often appears in the novels, even in Xenophon of Ephesus, see Doulamis 2007, and more generally the whole of Morgan \& Jones 2007. Platonic theories may have been transmitted through scholarship rather than a personal implication in philosophy, see for instance Alcinoos (Whittaker \& Louis 1990).

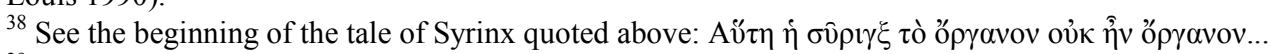

${ }^{39}$ See Zeitlin 1990 and 1994, and Winkler 1990. See also Alaux and Létoublon 2005.
} 
given by the queen with the child to Sisimithres, when deciphered by Calasiris, well attests. The painting comes to the fore in the dénouement, in book 10, when it is necessary for Charicleia to prove her ascendance through her striking resemblance with Andromeda on the painting, and the black ring on the white skin of her arm. ${ }^{40}$ The resemblance between Charicleia and the Andromeda of the myth on the painting well implies a relation of modeling, but Heliodorus does not need a narration for suggesting this very presence.

Novels show how young characters imitate mythical models in their evolution from paides to teenagers and adults: the novel puts on stage the rite de passage, as Dowden (1999), following Van Gennep, has shown. But Pan himself seems to transform himself, up from an erotic maniac to a peaceful protector: the association of Pan, the Nymphs and Eros as protecting gods for Daphnis and Chloe

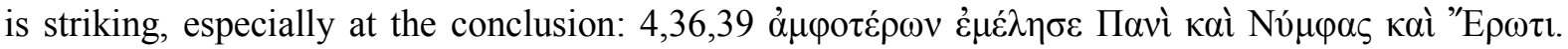
Eros is called Daphnis' and Chloe's shepherd (poimen) in the garden of Philetas, but the whole Trinity constituted by Pan, Eros and the Nymphs may be called thus. We have tried to show the importance of imitation, mimesis, in the link towards Platonic ideas between the tale proper and the myths told in the tale within the tale. Achilles Tatius, with some allusions such as the Magnetic stone, confirms in a somehow pedantic way - pedantry is moderated by irony - the knowledge of philosophical literature. This magistral achievement is found in the Aethiopica, where the myths need no narrative to be deeply present in the voyage of the heroes towards their country. The Platonic atmosphere is constantly present in the drawing of their souls to each other, symbolized by their radiant beauty, as a reflection of their souls on their faces and bodies.

\section{Bibliography}

Alaux, J., Létoublon, F. 2005. 'La grotte et la source. Paysage naturel et artifice dans Daphnis et Chloé et Leucippé et Clitophon', in: B. Pouderon (ed.), Lieux, décors et paysages de l'ancien roman des origines à Byzance, Lyon: Maison de l'Orient et de la Méditerranée, 57-74.

Bartsch, S. 1989. Decoding the Ancient Novel: The Reader and the Role of Description in Heliodorus and Achilles Tatius, Princeton: Princeton University Press.

Bowie, E. 2005. 'Metaphor in Daphnis and Chloe', in: S. Harrison, M. Paschalis, S. Frangoulidis (eds.), Metaphor and the Ancient Novel, Ancient Narrative Supplementum 4, Groningen: Barkhuis \& Groningen University Library, 68-86.

2008. 'Literary Milieux', in Whitmarsh (ed.), 17-38.

Bowie, E. 2009. 'The Uses of Bookishness', in: M. Paschalis, S. Panayotakis, G. Schmeling (eds.), Readers and Writers in the Ancient Novel, Ancient Narrative Supplementum 12, Groningen: Barkhuis \& Groningen University Library, 115-126.

Cameron, A. 2004. Greek Mythography in the Roman World, Oxford, New York: Oxford University Press.

Chalk, H.H.O. 1960. 'Eros and the Lesbian Pastoral of Longus', JHS 180, 32-61.

Crismani, D. 1997. Il teatro nel romanzo ellenistico d'amore e di avventure, Alessandria: Ed. dell'Orso.

Cueva, E.P. 2004. The Myths of Fiction: Studies in the Canonical Greek Novels, Ann Arbor: University of Michigan Press.

Curtius, E.R. 1990. European Literature and the Latin Middle Ages, transl. by W.R. Trask, with a new afterword by P. Godman, 7th ed., Princeton, NJ: Princeton University Press.

Di Marco, L. 2000. 'Fileta praeceptor amoris: Longo Sofista e la correzione del modello bucolico', SCO 47, 9-35.

\footnotetext{
${ }^{40}$ Létoublon 1992; 1993, 134-136. Since Achilles Tatius has a detailed ekphrasis of an Andromeda delivered by Perseus, symmetrical to a Prometheus and Herakles, the comparison is striking: Tatius complacently describes Andromeda' pallor, her almost blue skin at the extremities indicating she is almost dying. Heliodorus, in contrast to this taste for ekphrasis, seems to avoid it mostly, or even to delete the most characteristic ekphrases, awaited for by the readers. He is nevertheless a kind of virtuoso in this genre, when he wants to, like the description of Charicleia's ring (Létoublon 1992).
} 
Doulamis, K. 2007. 'Stoic Echoes and Style in Xenophon of Ephesus', in: Morgan, Jones (eds.), 151175.

Dowden, K. 1999. 'Fluctuating Meanings: "Passage Rites" in Ritual, Myth, Odyssey, and the Greek Romance', in: M.W. Padilla (ed.), Rites of Passage in Ancient Greece: Literature, Religion, Society, Lewisburg: Bucknell University Press, 221-243.

Dubel, S. 2006. 'L'hirondelle et l'épervier, le rossignol et la huppe (Achille Tatius, Leucippé et Clitophon V, 3-5): notes sur la difficulté d'établir un mythe', in: V. Gély, J.-L. Haquette, A. Tomiche (eds.), Philomèle. Figures du rossignol dans la tradition littéraire et artistique, Clermont-Ferrand: Presses Universitaires Blaise Pascal, 37-52.

Durham, D.B. 1938. 'Parody in Achilles Tatius', CPh 33, 1-19.

Effe, B. 1982. 'Longos: Zur Funktionsgeschichte der Bukolik in der römischen Kaiserzeit', Hermes 110, 65-84; transl. as 'Longus: Towards a History of Bucolic and its Function in the Roman Empire', in: S. Swain (ed.), Oxford Readings in the Greek Novel, Oxford: Oxford University Press 1999, 189209.

Fusillo, M. 1989. Il romanzo Greco: polifonia ed eros, Venezia: Marsilio.

1990. 'Il testo nel testo: la citazione nel romanzo greco', $M D 25,27-48$.

Garnaud J.-P. 1991. Achille Tatius d'Alexandrie, Le roman de Leucippé et Clitophon, Paris: Les Belles Lettres.

Gély-Ghedira, V. 2000. La Nostalgie du moi: Echo dans la littérature européenne, Paris: Presses Universitaires de France.

Goldhill, S. 2001. 'The erotic eye: visual stimulation and cultural conflict', in: S. Goldhill (ed.), Being

Greek under Rome: Cultural Identity, the Second Sophistic and the Development of the Empire, Cambridge, New York: Cambridge University Press.

2008. 'Genre', in: Whitmarsh (ed.), 185-200.

Hunter, R. 1983. A Study of Daphnis and Chloe, Cambridge: Cambridge University Press.

— 1997. 'Longus and Plato', in: Picone, Zimmermann (eds.), 15-18.

Konstan, D. 2008 'The Active Reader and the Ancient Novel', in: M. Paschalis, S. Panayotakis, G. Schmeling (eds.), Readers and Writers in the Ancient Novel, Ancient Narrative Supplementum 12, Groningen: Barkhuis \& Groningen University Library, 1-17.

Laird, A. 2008. 'Approaching style and rhetoric', in: Whitmarsh (ed.), 201-217.

Larson, J. 2007. 'A Land Full of Gods: Nature Deities in Greek Religion', in: D. Ogden (ed.), A Companion to Greek Religion, Oxford: Blackwell, 57-70.

Ledbetter, G.M. 2003. Poetics before Plato: Interpretation and Authority in Early Greek Poetry, Princeton, NJ: Princeton University Press.

Létoublon, F. 1983. 'Le miroir et la boucle', Poétique 40, 19-35.

— 1992. 'Un bracelet d'ébène sur son bras d'ivoire', in: J.-M. Racault et al. (eds.), Métisages, SaintDenis de la Réunion: Harmattan, 83-97.

— 1993. Les lieux communs du roman: stéréotypes grecs d'aventure et d'amour, Mnemosyne Supplementa 123, Leiden: Brill.

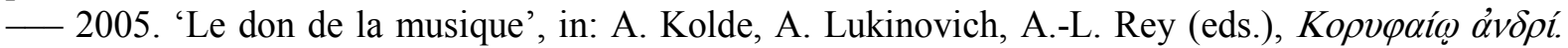
Mélanges offerts à André Hurst, Genève: Droz, 191-201.

— 2007. 'L'Amour athlète', in: S. David, É. Geny (eds.), Troîka, parcours antiques. Mélanges offerts a Michel Woronoff 1, Besançon: Presses Universitaires de Franche-Comte, 331-340.

— 2008. 'Pirates des cours', in: D. Auger, E. Wolff (eds.), Culture classique et christianisme. Mélanges offerts à Jean Bouffartigue, Paris: Picard, 293-300.

— forthcoming (a). 'La pierre magnétique de l'amour', in: Hommage à Nicole Fick, Dijon. forthcoming (b). 'Magnetic stone of Love. Novel and Greek Poetry', in: The Blackwell Companion to the Ancient Novel, Oxford: Blackwell.

Létoublon, F., Boulic, N. forthcoming, 'The Pirates in the Library', in: M. Futre-Pinheiro (ed.), Proceedings of the International Conference on the Ancient Novel 2008.

Massin, M. 2001. Les figures du ravissement. Enjeux philosophiques et esthétiques, Paris: Le monde de l'éducation. 
Morales, H. 2004. Vision and Narrative in Achilles Tatius' Leucippe and Clitophon, Cambridge, New York: Cambridge University Press.

- 2008. 'The history of sexuality', in: Whitmarsh (ed.), 39-55.

Morgan, J.R. 2004. Longus, Daphnis and Chloe, Warminster: Aris and Phillips.

Morgan, J.R., Harrison, S. 2008. 'Intertextuality', in: Whitmarsh (ed.), 218-236 (Morgan, '1. The Greek Novel', 218-227; Harrison, '2. The Roman Novel', 227-236).

Morgan, J.R., Jones, M. (eds.), 2007. Philosophical Presences in the Ancient Novel, Ancient Narrative Supplementum 10, Groningen: Barkhuis \& Groningen University Library.

Morgan, J.R., Stoneman, R. (eds.), 1994. Greek Fiction: the Greek Novel in Context, London, New York: Routledge.

Nagy, G. 1992. 'Mythological exemplum in Homer', in: R. Hexter, D. Selden (eds.), Innovations of Antiquity, New York: Routledge, 311-331.

Pattoni, M.P. 2005. Longo Sofista, Dafni e Cloe, Milano: Biblioteca Universale Rizzoli.

Pecere, O., Stramaglia, A. (eds.), 1996. La letteratura di consumo nel mondo Greco-latino, Cassino: Università degli studi di Cassino.

Picone, M., Zimmermann, B. (eds.), 1997. Der antike Roman und seine mittelalterliche Rezeption, Basel, Boston: Birkhäuser.

Reardon, B.P. (ed.), 1989. Collected Ancient Greek Novels, Berkeley: California University Press.

- 1991. The Form of Greek Romance, Princeton.

Schmeling, G. (ed.), 2003. The Novel in the Ancient World, rev. ed., Boston, Leiden: Brill.

Selden, D. 1994. 'Genre of Genre', in: Tatum (ed.), 39-64.

Stephens, S.A. 2008. 'Cultural identity', in: Whitmarsh (ed.), 56-71.

Tatum, J. (ed.), 1994. The Search for the Ancient Novel, Baltimore: Johns Hopkins University Press.

Walden, J.W.H. 1894. 'Stage terms in Heliodorus' Aethiopica', HSCPh 5, 1-43.

Whitmarsh, T. 2001. Greek Literature and the Roman Empire: the Politics of Imitation, Oxford, New York: Oxford University Press.

— 2005. 'The Lexicon of Love: Longus and Philetas grammatikos', JHS 125, 145-148.

- 2008. 'Class', in: Whitmarsh (ed.), 72-87.

- (ed.), 2008. The Cambridge Companion to the Greek and Roman Novel, Cambridge: Cambridge University Press.

Whittaker, J., Louis, P. 1990. Alcinoos. Enseignement des doctrines de Platon, Paris: CUF.

Willcock, M. 1964. 'Mythological Paradeigma in Homer', CQ 14, 141-154.

— 1977. 'Ad hoc Invention in the Iliad, HSCPh 18, 41-53.

Winkler, J.J. 1990. The Constraints of Desire: the Anthropology of Sex and Gender in Ancient Greece, London: Routledge.

Zeitlin, F.I. 1990. 'The poetics of Eros: nature, art, and imitation in Longus' Daphnis and Chloe', in: D.M. Halperin, J.J. Winkler, F.I. Zeitlin (eds.), Before Sexuality: the Construction of Erotic Experience in the Ancient World, Princeton, NJ: Princeton University Press, 417-464.

— 1994. 'Gardens of Desire in Longus' Daphnis and Chloe. Nature, Art, and Imitation', in: Tatum (ed.), 148-170.

Zimmermann, B. 1997. 'Die Symphonie der Texte. Zur Intertextualität im griechischen Liebesroman', in: Picone, Zimmermann (eds.), 3-13. 